\title{
Neoplastic extracellular matrix environment promotes cancer invasion in vitro
}

\section{Sundquist, Elias}

2016-06-10

Sundquist, E, Renko, O , Salo , S, Magga, J, Cervigne , N K, Nyberg , P, Risteli , J , Sormunen, R, Vuolteenaho , O , Zandonadi , F , Leme , A F P , Coletta, R D , Ruskoaho , H \& Salo, T 2016 , ' Neoplastic extracellular matrix environment promotes cancer invasion in vitro ' , Experimental Cell Research, vol. 344 , no. 2 , pp. 229-240 . https://doi.org/10.1016/j.yexcr.2016.04.003

http://hdl.handle.net/10138/224064

https://doi.org/10.1016/j.yexcr.2016.04.003

publishedVersion

Downloaded from Helda, University of Helsinki institutional repository.

This is an electronic reprint of the original article.

This reprint may differ from the original in pagination and typographic detail.

Please cite the original version. 
Research article

\title{
Neoplastic extracellular matrix environment promotes cancer invasion in vitro
}

\author{
Elias Sundquist ${ }^{a, b, *}$, Outi Renko ${ }^{c, 1}$, Sirpa Salo ${ }^{a, b, d}$, Johanna Magga ${ }^{c}$, Nilva K. Cervigne ${ }^{e}$, \\ Pia Nyberg a,b,f, Juha Risteli ${ }^{\text {a,g,h }}$, Raija Sormunen ${ }^{\mathrm{i}, \mathrm{j}}$, Olli Vuolteenaho ${ }^{\mathrm{k}}$, Flávia Zandonadi ${ }^{1}$, \\ Adriana F. Paes Leme ${ }^{1}$, Ricardo D. Coletta ${ }^{e}$, Heikki Ruskoaho ${ }^{\mathrm{c}, \mathrm{m}}$, Tuula Salo ${ }^{\mathrm{a}, \mathrm{b}, \mathrm{n}}$ \\ ${ }^{a}$ Cancer and Translational Medicine Research Unit, University of Oulu, PO Box 5281, Aapistie 5A, FIN 90014 Oulu, Finland \\ ${ }^{\mathrm{b}}$ Medical Research Center, Oulu University Hospital, Oulu, Finland \\ ${ }^{\mathrm{c}}$ Department of Pharmacology and Toxicology, Research Unit of Biomedicine, University of Oulu, Oulu, Finland \\ ${ }^{\mathrm{d}}$ Faculty of Biochemistry and Molecular Medicine, University of Oulu, Oulu, Finland \\ e Department of Oral Diagnosis, Oral Pathology Division, Piracicaba Dental School, University of Campinas, Campinas, Brazil \\ ${ }^{\mathrm{f}}$ Biobank Borealis of Northern Finland, Oulu University Hospital, Oulu, Finland \\ ${ }^{\mathrm{g}}$ Department of Clinical Chemistry, Institute of Diagnostics, University of Oulu, Oulu, Finland

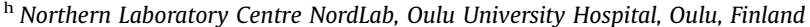 \\ ${ }^{\mathrm{i}}$ Biocenter Oulu, Oulu, Finland \\ ${ }^{\mathrm{j}}$ Department of Pathology, Institute of Diagnostics, University of Oulu, Oulu, Finland \\ ${ }^{\mathrm{k}}$ Department of Physiology, Institute of Biomedicine, University of Oulu, Oulu, Finland \\ ${ }^{1}$ Mass Spectrometry Laboratory, Brazilian Biosciences National Laboratory-CNPEM, Campinas, Brazil \\ ${ }^{m}$ Division of Pharmacology and Pharmacotherapy, University of Helsinki, Helsinki, Finland \\ ${ }^{n}$ Department of Oral and Maxillofacial Diseases, University of Helsinki, and HUSLAB, Helsinki, Finland
}

\section{A R T I C L E I N F O}

\section{Article history:}

Received 15 March 2016

Accepted 7 April 2016

Available online 20 April 2016

Keywords:

Carcinoma

Extracellular matrix

Invasion

migration

Myoma

Organotypic model

\begin{abstract}
A B S T R A C T
The invasion of carcinoma cells is a crucial feature in carcinogenesis. The penetration efficiency not only depends on the cancer cells, but also on the composition of the tumor microenvironment. Our group has developed a 3D invasion assay based on human uterine leiomyoma tissue. Here we tested whether human, porcine, mouse or rat hearts as well as porcine tongue tissues could be similarly used to study carcinoma cell invasion in vitro. Three invasive human oral tongue squamous cell carcinoma (HSC-3, SCC25 and SCC-15), melanoma (G-361) and ductal breast adenocarcinoma (MDA-MB-231) cell lines, and cocultures of HSC-3 and carcinoma-associated or normal oral fibroblasts were assayed. Myoma tissue, both native and lyophilized, promoted invasion and growth of the cancer cells. However, the healthy heart or tongue matrices were unable to induce the invasion of any type of cancer cells tested. Moreover, when studied in more detail, small molecular weight fragments derived from heart tissue rinsing media inhibited HSC-3 horizontal migration. Proteome analysis of myoma rinsing media, on the other hand, revealed migration enhancing factors. These results highlight the important role of matrix composition for cancer invasion studies in vitro and further demonstrate the unique properties of human myoma organotypic model.
\end{abstract}

(c) 2016 Elsevier Inc. All rights reserved.
Abbreviations: CAF, carcinoma-associated fibroblast; CHX, chlorhexidine; ECM, extracellular matrix; EMT, epithelial-mesenchymal transition; FGF, fibroblast growth factor; HGF, hepatocyte growth factor; ICTP, carboxy-terminal peptide of type I collagen; IIICTP, carboxy-terminal peptide of type III collagen; LFQ label-free quantification; NOF, normal oral fibroblast; OSCC, oral squamous cell carcinoma; OTSCC, oral tongue squamous cell carcinoma; RIA, radioimmunoassay; RM, rinsing media; SEM, scanning electron microscopy; TEM, transmission electron microscopy; TGF- $\beta$, transforming growth factor beta; TME, tumor microenvironment; TNC, tenascin-C.

* Corresponding author.

E-mail address: elias.sundquist@oulu.fi (E. Sundquist).

${ }^{1}$ Outi Renko passed away in 2015

\section{Introduction}

Cancer cell invasion is the first fatal step towards metastases which mostly leads to the patients' death. Therefore, the invasion activity of the tumor cells serves as an important prognostic factor in cancers $[13,14]$. Currently in vitro and in vivo studies concentrate the attention mainly on characterization of the genetic profile and proliferative activities of cancer cells. However, while mutation landscape and the cell proliferation rate are important in carcinogenesis, they alone are not sufficient factors to define the 
severity of the disease. Indeed, in many cancers the pattern of extracellular matrix (ECM) invasion is a more significant prognosticator than the mitotic activity of the cells [4]. In the fibroblastic invasion pattern, elongated mesenchymal cells have increased traction forces that reorganize and degrade the ECM $[27,32]$. In addition to the proteolytic remodeling of ECM, some cancers adopt amoeboid migration characteristics and invade mainly using biomechanical forces. Eventually the crosstalk between the ECM and the cancer cells determine the invasion efficiency. Therefore, the tumor microenvironment (TME) containing e.g. cancer-associated fibroblasts (CAFs), endothelial and inflammatory cells; cytokines and proteases, is getting in the focus of cancer research $[3,14]$.

In vitro, the $3 \mathrm{D}$ invasion pattern has been studied with organotypic models composed of rat tail type I collagen as well as commercial mouse tumor derivatives, such as Matrigel [21]. However, these classical methods that combine matrix from different species do not accurately mimic the composition of human TME. Our group has developed a 3D invasion assay using human uterine leiomyoma tissue [23]. This model, applied already in more than 20 publications, provides a hypoxic matrix containing essential TME components for in vitro invasion experiments $[1,2,5,8,15,24,30,31,33]$. In myoma tissue, invasion efficiency can be analyzed by determining the collagen degradation (carboxyterminal peptide of type I or III collagen - ICTP or IIICTP - radioimmunoassay measurements from the culture media) together with histological and immunohistological staining of the tissue sections [23]. The latter method elucidates the cancer cell growth pattern and the former determines whether proteolytic ECM degradation or amoeboid movement predominates in the invasion process.

In this study, we compared the suitability of heart or tongue solid tissue discs to myoma discs for cancer invasion assays. We also elucidated whether lyophilized and rehydrated myoma retains its invasion inductive properties. Finally, we tested the effects of the rinsing media (RM) from myoma and heart tissue discs on the migration of tongue carcinoma cells.

\section{Materials and methods}

\subsection{Cell culture}

Three different oral tongue squamous cell carcinoma (OTSCC) cell lines were used in this study: SCC-15 $\left(\right.$ ATCC $^{\circledR}$ CRL-1623TM, LGC Standards AB, Boras, Sweden), SCC-25 (ATCC ${ }^{\circledR}$ CRL-1628 ${ }^{\mathrm{TM}}$, LGC Standards AB) and HSC-3 (JCRB 0623, Osaka National Institute of Health Sciences, Osaka, Japan). The cells were cultivated in DMEM/ F-12 (Invitrogen, Carlsbad, CA) with 10\% heat-inactivated fetal bovine serum (FBS) (Perbio Science, Erembodegem, Belgium), $100 \mathrm{U} / \mathrm{ml}$ penicillin, $100 \mu \mathrm{g} / \mathrm{ml}$ streptomycin, $50 \mu \mathrm{g} / \mathrm{ml}$ ascorbic acid, $250 \mathrm{ng} / \mathrm{ml}$ Fungizone, $5 \mu \mathrm{g} / \mathrm{ml}$ insulin (bovine pancreas) and $0.4 \mathrm{ng} / \mathrm{ml}$ hydrocortisone (supplements from Sigma-Aldrich, Ayrshire, UK). The cells were cultivated in a humidified atmosphere of $5 \% \mathrm{CO}_{2}$ at $37{ }^{\circ} \mathrm{C}$ and passaged routinely using trypsin-EDTA (Sigma-Aldrich). Carcinoma-associated fibroblasts (CAFs), CaDEC12, were a kind gift from Dr. Daniela Costea, University of Bergen, Norway. CAFs were derived from a specimen of OTSCC [11]. CaDEC12 were cultivated in high-glucose DMEM (Sigma-Aldrich) with $100 \mathrm{U} / \mathrm{ml}$ penicillin, $100 \mu \mathrm{g} / \mathrm{ml}$ streptomycin, $50 \mu \mathrm{g} / \mathrm{ml}$ ascorbic acid, $250 \mathrm{ng} / \mathrm{ml}$ Fungizone, $1 \mathrm{mmol} / \mathrm{L}$ sodium pyruvate, and $10 \%$ heat-inactivated FBS. Normal oral fibroblasts (NOF) were isolated from normal superfluous buccal mucosa tissue after wisdom tooth extraction [10]. NOFs were cultivated similarly to CAFs. Malignant melanoma cells G-361 (ATCC ${ }^{\circledR}$ CRL-1424TM, LGC Standards $\mathrm{AB}$ ) and breast adenocarcinoma cells MDA-MB-231 (ATCC ${ }^{\circledR}$
HTB-26 ${ }^{\mathrm{TM}}$, LGC Standards AB) from metastatic sites were also used. G-361 cells were cultivated in CAF media and MDA-MB-231 cells in HSC-3 media, both described above.

\subsection{Myoma organotypic assay}

The study was approved by the Ethics Committee of the Oulu University Hospital. Uterine leiomyoma tissues were obtained from routine surgeries of otherwise healthy donors after an informed consent. The freshly-dissected myoma tissue was cut into $3 \mathrm{~mm}$ slices and the discs were made using an $8 \mathrm{~mm}$ biopsy punch. Only the non-degenerated myomas were picked and discs from the same myoma (an average of 100 discs/myoma) were used in each experimental set-up. The myoma discs were stored at $-70{ }^{\circ} \mathrm{C}$ in DMEM/F-12 media with $10 \%$ DMSO (Sigma-Aldrich). The cells were cultivated on top of myoma discs for 14 days as described by [23]. Briefly, the discs were put into Transwell inserts (diameter $6.5 \mathrm{~mm}$, pore size $8 \mu \mathrm{m}$, Corning Inc., Corning, NY, USA) and the HSC-3 cells $(700,000$ in $50 \mu \mathrm{l})$ were plated on top of each disc. The cells were allowed to attach to the discs and on the next day the discs were removed from the Transwell inserts and put onto uncoated nylon mesh resting on a curved steel grid in a 12well plate with $1 \mathrm{ml}$ of medium. The media were analyzed using radioimmunoassay (RIA) to detect type III collagen degradation products, as described by [23]. After 14 days the discs were prepared for histology as described below.

To lyophilize the myoma discs they were first put onto 24-or 48-well plates, one disc per well, covered with parafilm and frozen at $-70^{\circ} \mathrm{C}$. The parafilm was pierced and the discs were lyophilized for $72 \mathrm{~h}$ using a Heto Drywinner DW3 (Heto-Holten A/S, Allerød, Denmark). After lyophilization the discs were placed in an exicator and stored at $-70^{\circ} \mathrm{C}$. The discs were rehydrated by rinsing them at $4{ }^{\circ} \mathrm{C}$ in DMEM/F-12 overnight. After rehydration the discs were used in the same manner as non-lyophilized native discs.

\subsection{Scanning electron microscopy (SEM)}

For SEM images (Fig. 1(A)) 700,000 HSC-3 cells were cultivated on top of myoma discs for 10 days as described above. For SEM the discs were dehydrated in an ascending ethanol series: overnight in $40 \%, 1 \mathrm{~d}$ in $50 \%$ and 3 days in $70 \%$ ethanol. To reveal the invaded cells inside the myoma, the discs were bisected. Dehydration was completed with $5 \mathrm{~min}$ in 80\%, $5 \mathrm{~min}$ in $90 \%$ and twice for $5 \mathrm{~min}$ in $100 \%$ ethanol. After dehydration, a critical point drying was performed using a BAL-TEC Critical Point Dryer 030. Next the samples were attached to a metal platform using a two-sided carbon sticker and sputtered with a 6-12 nm platinum layer using an Agar High Solution Sputter Coater. Images were captured using Zeiss Ultra Plus field emission scanning electron microscope with $3.00 \mathrm{kV}$ acceleration voltage and 8500x magnification.

\subsection{Transmission electron microscopy (TEM)}

For TEM images HSC-3 cells were cultivated in co-cultures with mesenchymal stem cells (400,000 of both cells, 14 days) (Fig. 1(C)) or with normal fibroblasts (400,000 of both cells, 14 days) (Fig. 1 (D)) for 10 days. Samples were cut from the top of the myoma discs and fixed in $1 \%$ glutaraldehyde $4 \%$ formaldehyde mixture in $0.1 \mathrm{M}$ phosphate buffer. They were post-fixed in $1 \%$ osmium tetroxide, dehydrated in acetone and embedded in Epon LX 112 (Ladd Research Industries, Williston, Vermont, USA). Thin sections were cut with Leica Ultracut UCT ultramicrotome, stained in uranyl acetate and lead citrate and examined in Philips CM100 transmission electron microscope. Images were captured with Morada CCD camera (Olympus Soft Imaging Solutions GMBH, Munster Germany). 

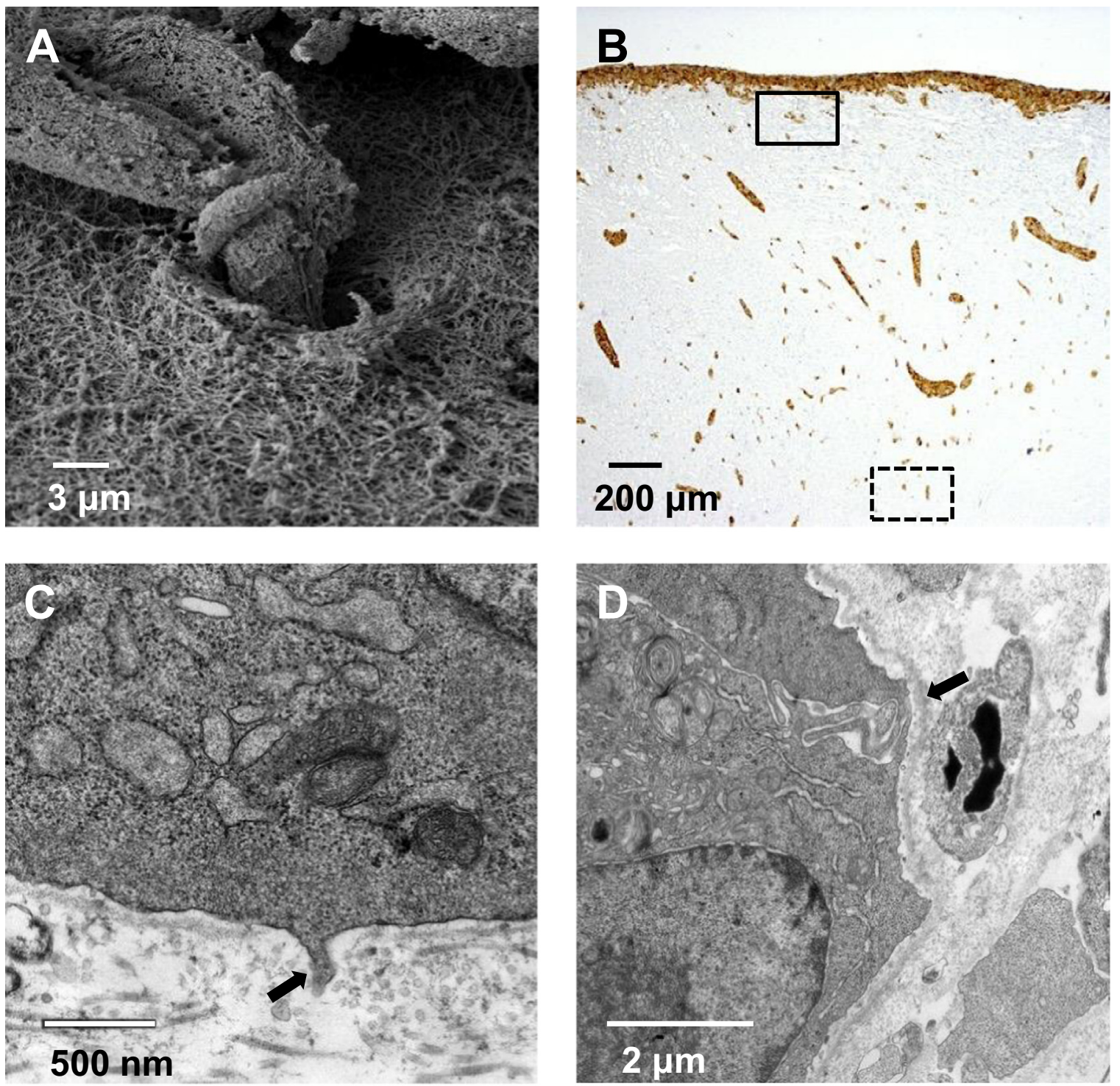

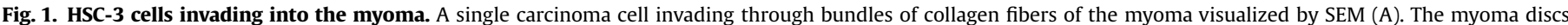

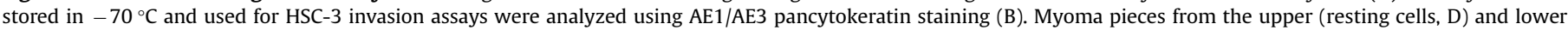

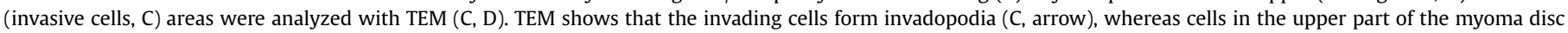
contained basement membrane structures surrounding the cells (D, arrow).

\subsection{Heart invasion assay}

The human heart sample was a kind gift from Prof. Miklós Tóth, Semmelweis University, Budapest, Hungary. Sample collection was approved by the Health and Scientific Research Ethical Committee in Budapest. The porcine heart was collected from a blood donor pig from the Laboratory Animal Centre, University of Oulu, immediately after sacrificing. The porcine heart discs were prepared from the left ventricle and were further processed as described above for the myoma organotypic culture.

Mouse and rat hearts were collected from healthy animals from the Laboratory Animal Centre, University of Oulu. The animals were sacrificed, and the hearts were removed and stored at $-70{ }^{\circ} \mathrm{C}$. When still frozen, the tissue was cut into $3 \mathrm{~mm}$ slices with a disposable scalpel and further into discs with a $3 \mathrm{~mm}$ biopsy punch. Heart discs were equilibrated in media at room temperature (RT) for one hour to prepare organotypic cultures. The heart discs were placed into Transwell inserts (CellCrown ${ }^{\mathrm{TM}}$ 96, diameter $3 \mathrm{~mm}$; Scaffdex, Tampere, Finland) and 100,000 cells in $10 \mu \mathrm{l}$ of media were added on top of the discs. The heart organotypic cultures were sustained and the media was changed every 2-3 days. Collection of all animal hearts used in this study was approved by National Animal Experiment Board in Finland (ELLA).

\subsection{Porcine tongue organotypic assays}

The healthy porcine tongues were collected from the Laboratory Animal Centre, University of Oulu, immediately after sacrificing the pig that had been used by another research group who studied bone marrow mononuclear cell migration to ischemic brain tissue [19]. Their study was approved by the Research Animal Care and Use Committee of the University of Oulu. Tongues were stored at $-70^{\circ} \mathrm{C}$. The tongues were first sterilized by dipping for 5 seconds in $70 \%$ ethanol followed by shaping the discs with an $8 \mathrm{~mm}$ biopsy punch from the lateral border of the tongues (Fig. 2 (C)). The experiments with tongue discs were modified in three different ways. The discs were stored either overnight at $4{ }^{\circ} \mathrm{C}$, or in an incubator $\left(37^{\circ} \mathrm{C}, 5 \% \mathrm{CO}_{2}\right)$, or they were taken straight from the freezer $\left(-70{ }^{\circ} \mathrm{C}\right)$ and thawed just before the invasion assay was started. The process is illustrated in Fig. 2. The tongue discs were 


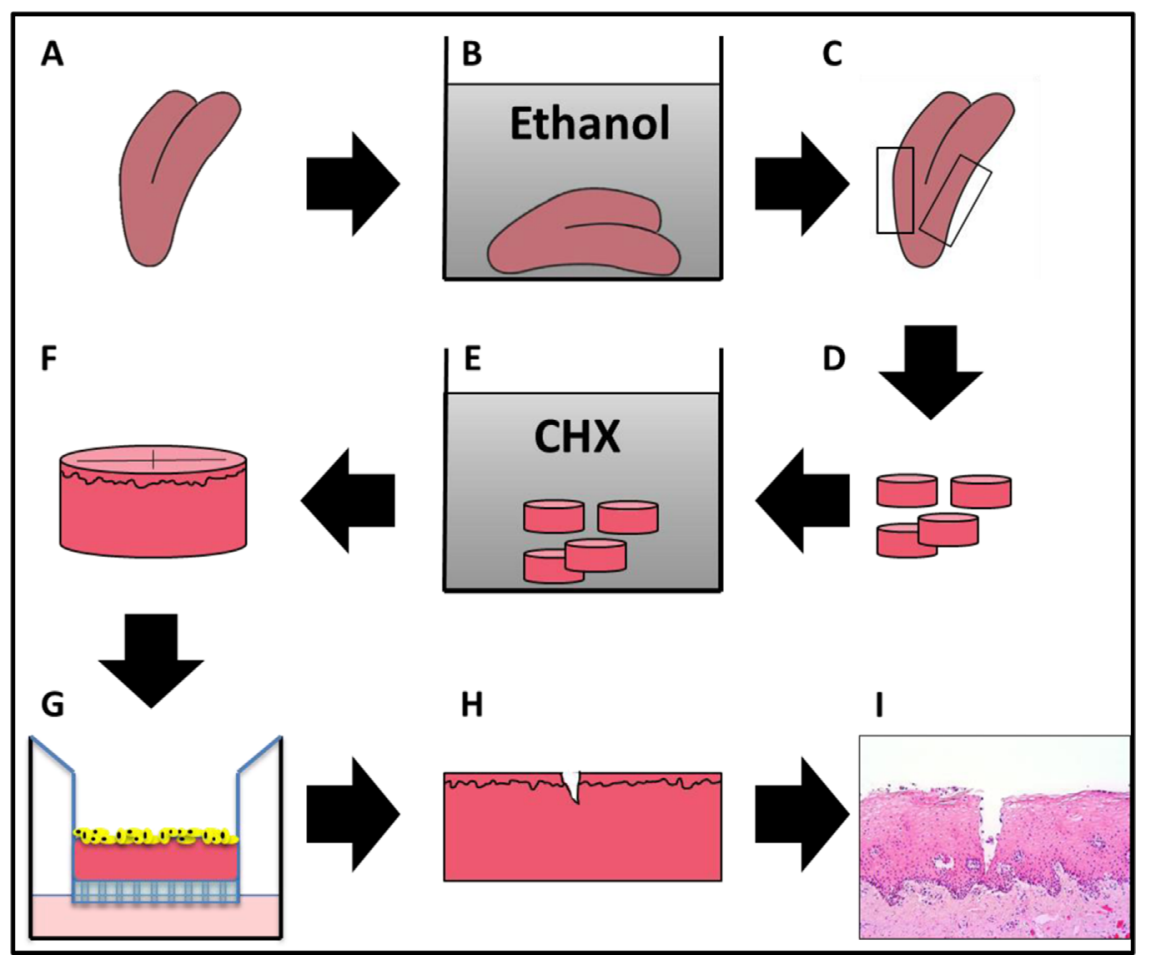

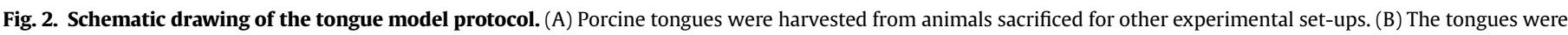

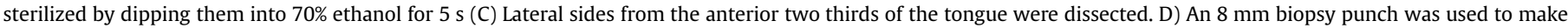

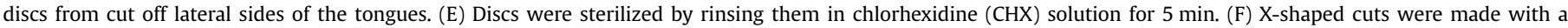

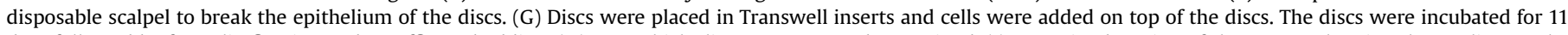

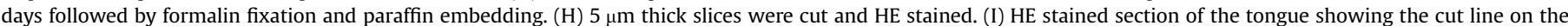
epithelial surface.

rinsed then in $0.2 \%$ chlorhexidine gluconate for 5 min (GlaxoSmithKline Oy, Corsodyl, chlorhexidine gluconate $2 \mathrm{mg} / \mathrm{ml}$, Consumer Healthcare, Espoo) and the epithelium of the tongue was injured using either the tip of a plastic pipette to create small scratches, sharp tipped tweezers to create wounds or surgical knife to make X-shaped cuts through the keratinized epithelial surface. After punching the discs, they were transferred into Transwell inserts and DMEM/F-12 cell culture medium containing complete serum $(600 \mu \mathrm{l})$ was added into the lower compartment and cells $(200,000$ in $50 \mu \mathrm{l})$ were added on top of the discs. Media were changed daily during the 9-11 days of incubation. After the incubation the discs were fixed in $4 \%$ formalin $(24 \mathrm{~h})$. The preparation of histological sections and immunohistology is described below.

\subsection{Invasion assay with HSC-3 and CAFs or NOFs}

HSC -3 cells (200,000 in $50 \mu \mathrm{l})$ were applied on top of myoma or tongue discs (with cuts as described above) with or without CAFs or NOFs $(200,000$ in $50 \mu \mathrm{l})$. All cells were fluorescently labeled with lipophilic long-chain dialkylcarbocyanine stains, HSC-3 cells with green (DiO) and CAFs/NOFs with red dye (Dil) (Vybrant labels, Invitrogen). Normal DMEM/F-12 media and myoma RM were used for tongue discs and only normal medium for myoma discs. The incubation time was 11 days. The sections were DAPI stained and photographed using an AMG EVOS $_{\mathrm{fl}}$ microscope system.

\subsection{Histology and immunohistochemistry}

The organotypic cultures were fixed at day 14 (day 9 or 11 for porcine tongue assays) in $4 \%$ neutral-buffered formalin overnight. The samples were dehydrated, bisected and embedded in paraffin. $6 \mu \mathrm{m}$ sections were deparaffinized and stained with Mayer's HE.
The endogenous peroxidase activity was blocked with $\mathrm{H}_{2} \mathrm{O}_{2}$ in $\mathrm{MeOH}$ for $30 \mathrm{~min}$ for pancytokeratin AE1/AE3 (Dako) staining. Antigen retrieval was performed by $0.4 \%$ pepsin in $0.01 \mathrm{M} \mathrm{HCl}$ at $37{ }^{\circ} \mathrm{C}$ for $20 \mathrm{~min}$. Sections were blocked in $2 \%$ bovine serum albumin (BSA)/PBS for $30 \mathrm{~min}$ and incubated with primary antibodies in a humidified chamber at $37{ }^{\circ} \mathrm{C}$ for $30 \mathrm{~min}$ and at $4{ }^{\circ} \mathrm{C}$ overnight. Dilution (1:150) was prepared in REAL Antibody diluent (Dako). Biotinylated secondary antibody anti-mouse was applied for $1 \mathrm{~h}$ and StreptABComplex/horseradish peroxidase (HRP, Dako) in $0.5 \mathrm{M} \mathrm{NaCl} / \mathrm{PBS}$ was applied for $30 \mathrm{~min}$. Between each step the sections were washed twice in PBS for $10 \mathrm{~min}$.

Myomas were stained for tenascin-C (TNC) as follows: for epitope retrieval, the sections were heated in a microwave oven in Tris-EDTA solution ( $\mathrm{pH}$ 9) for $10 \mathrm{~min}$ and allowed to cool down at RT for 20 min Endogenous peroxidase activity was blocked using DAKO Peroxidase-blocking solution S2023 for 10 min The sections were then incubated with primary antibody (DB7, order \#610003, Biohit, Helsinki, Finland) at a dilution of 1:500 for $60 \mathrm{~min}$ at RT. For visualization, HRP was introduced to the slides for $10 \mathrm{~min}$, after which DAB chromogen was used for $5 \mathrm{~min}$, the sections were counterstained using Mayer HE for $1 \mathrm{~min}$ and mounted mechanically. No quantifications were performed from TNC stained myoma sections.

Myoma and heart organotypic assays performed with G-361 cells were stained with $\mathrm{S} 100$. The antigen retrieval was performed by $0.4 \%$ pepsin in $0.01 \mathrm{M} \mathrm{HCl}$ at $37{ }^{\circ} \mathrm{C}$ for $30 \mathrm{~min}$. The sections were incubated overnight at $4{ }^{\circ} \mathrm{C}$ with polyclonal rabbit anti-human S100 antibody (Dako Z0311, 1:3000).

From stained sections, the maximum invasion depth and/or area of invaded cells were quantified as described by [23]. 


\subsection{Radioimmunoassay}

A type III collagen C-terminal peptide (IIICTP) radioimmunoassay was used to investigate if invading cells degraded type III collagen when invading the ECM of tissue discs. Polyclonal antibody against IIICTP was raised in rabbits [22]. The IIICTP antigen was a synthetic peptide SP99 (NeoMPS). The synthetic peptide was conjugated to bovine thyroglobulin with carbodiimide (EDC; Pierce), according to the manufacturer's instructions. The dialyzed conjugate was emulsified with $0.9 \% \mathrm{NaCl}$ and Freunds adjuvant (Sigma) and injected subcutaneously into rabbits at three- to four-week intervals.

Polyclonal antiserum for SP99 was diluted for IIICTP-RIA. SP99 was labeled by the Chloramine-T method using ${ }^{125}$ I [29]. An extra tyrosine was added to the C-terminus of SP99 to facilitate radioiodination. To create a standard curve, serial dilutions of SP99 were used. $100 \mu \mathrm{l}$ of tissue sample media were incubated with $200 \mu \mathrm{l}$ of the antiserum dilution and $200 \mu \mathrm{l}$ of ${ }^{125}$ I-SP99 solution at $37{ }^{\circ} \mathrm{C}$ for $2 \mathrm{~h}$. Next $500 \mu \mathrm{l}$ of the secondary goat anti-rabbit antibody $(200 \mu \mathrm{g} / \mathrm{ml}$, Fitzgerald) in $15 \%$ polyethylene glycol (6 kDa) was added and the samples were incubated at $4{ }^{\circ} \mathrm{C}$ for $30 \mathrm{~min}$ The samples were centrifuged at $2000 \times \mathrm{g}$ at $4{ }^{\circ} \mathrm{C}$ for $30 \mathrm{~min}$ after which the radioactivity of the precipitates was measured with a gamma counter (Wizard 1470; Wallac).

\subsection{Gel filtration chromatography and wound healing assay}

Aliquots of the heart tissue RM $(3.5 \mathrm{ml})$ and myoma tissue RM $(13 \mathrm{ml})$ were lyophilized. The dry residues were each re-dissolved in $3 \mathrm{ml}$ of $0.1 \mathrm{M}$ ammonium acetate ( $\mathrm{pH} 6$ ), and applied separately to a Sephadex G-75 gel filtration column $\left(2.5 \times 28 \mathrm{~cm}^{2}\right)$ and eluted with the same buffer at $54 \mathrm{ml} / \mathrm{h}$. Fractions of $9 \mathrm{ml}$ were collected. The absorbance at $280 \mathrm{~nm}$ was measured using a Nanodrop spectrophotometer (Thermo Scientific). The effect on cell migration was tested by pooling the aliquots from three adjacent fractions (5-7, 8-10, 11-13, 14-16, and 17-19). The test samples were lyophilized, redissolved in the cell culture medium and their effect on cell migration was studied in a wound healing assay as described [31]. Briefly, HSC-3 cells were grown to confluency, wounds were created with a $1 \mathrm{ml}$ pipette tip and the wound closure was monitored. The wound healing rate was determined as a comparison of initial wound area to the wound area after $20 \mathrm{~h}$ of cultivation.

\subsection{Mass spectrometry}

The protein content of myoma RM was assessed using mass spectrometry. First, six myoma discs were rinsed for $24 \mathrm{~h}$. Next the rinsing media were combined into two pools each containing rinsing media from three myomas. Mass spectrometry analysis was performed for both pools.

The rinsing media were concentrated using a $3 \mathrm{kDa}$ centrifugal filter (Amicon Ultra, Millipore, Ireland) at $4{ }^{\circ} \mathrm{C}$, and the proteins were treated with a final concentration of $1.6 \mathrm{M}$ urea. The samples were reduced ( $5 \mathrm{mM}$ dithiothreitol, $25 \mathrm{~min}$ at $\left.56^{\circ} \mathrm{C}\right)$, alkylated (14 $\mathrm{mM}$ iodoacetamide, $30 \mathrm{~min}$ at RT in the dark) and digested with trypsin $(1: 50, \mathrm{w} / \mathrm{w})$. The reaction was stopped with $1 \%$ trifluoroacetic acid and desalted with Sep-pack cartridges. The samples were dried in a vacuum concentrator, reconstituted in $0.1 \%$ formic acid and analyzed by LC-MS/MS. Two independent experiments were performed.

An aliquot containing $3 \mu \mathrm{g}$ of proteins was analyzed on an electron-transfer dissociation enabled LTQ Orbitrap Velos Mass Spectrometer (Thermo Fisher Scientific, USA) connected to a nanoflow liquid chromatography column (LC-MS/MS) by an EASYnLC System (Proxeon Biosystem) through a proxeon nanoelectrospray ion source. Peptides were separated by a $2-90 \%$ acetonitrile gradient in an analytical PicoFrit column $(20 \mathrm{~cm} \times$ id $75 \mu \mathrm{m}, 5 \mu \mathrm{m}$ particle size, New Objective) at a flow of $300 \mathrm{nl} / \mathrm{min}$ over 212 min The nanoelectrospray voltage was set to $2.2 \mathrm{kV}$, and the source temperature was $275^{\circ} \mathrm{C}$. All instrumental methods for the LTQ Orbitrap Velos were set up in the data-dependent analysis mode. The full scan MS spectra $(m / z 300-1600)$ were acquired in the Orbitrap analyzer after accumulation to a target value of $1 \mathrm{e}^{6}$. The resolution in the Orbitrap was set to $r=60000$. The 20 most intense peptide ions with charge states $\geq 2$ were sequentially isolated to a target value of 5000 and fragmented in the linear ion trap by low-energy collision-induced dissociation (normalized collision energy of 35\%). The signal threshold for triggering an MS/ MS event was set to 1000 counts. Dynamic exclusion was enabled with an exclusion size list of 500, an exclusion duration of $60 \mathrm{~s}$, and a repeat count of 1 . An activation $\mathrm{q}=0.25$ and an activation time of $10 \mathrm{~ms}$ were used.

The raw files were processed using the MaxQuant version 1.2.7.429 and the MS/MS spectra were searched using the Andromeda search engine against the Uniprot Human Protein Database (release July 11, 2012; 69,711 entries). The initial maximal allowed mass tolerance was set to $20 \mathrm{ppm}$ for precursor and then set to $6 \mathrm{ppm}$ in the main search and to $0.5 \mathrm{Da}$ for fragment ions. Enzyme specificity was set to trypsin with a maximum of two missed cleavages. Carbamidomethylation of cysteine (57.021464 Da) was set as a fixed modification, and oxidation of methionine (15.994915 Da) and protein N-terminal acetylation (42.010565 Da) were selected as variable modifications. The minimum peptide length was set to 6 amino acids. Label-free protein quantification was performed using a previously described label-free quantification (LFQ) algorithm implemented in the MaxQuant software with a 2 min window for matching between runs and maximum $1 \%$ peptide and $1 \%$ protein false discovery rate (Cox \& Mann 2008). Protein intensity values were normalized using the LFQ algorithm available through the MaxQuant program and used to further identify differentially expressed proteins. Bio information analyses of the data were performed using Perseus v.1.2.7.4 software. Reverse and "only identified by site" entries were excluded. LFQ intensity values were $\log 2$ transformed; the dataset was filtered by two minimum valid values in at least one group, and statistical significance was assessed by applying Student's $t$-test to identify differentially expressed proteins.

\subsection{Statistical analysis}

Data were analyzed with independent samples $t$-test (IBM SPSS Statistics version 21) and results were considered to be statistically significant if the p-value was lower than 0.05 . P-values are represented in figures as ${ }^{*} \mathrm{p} \leq 0.05,{ }^{* *} \mathrm{p} \leq 0.01$ and ${ }^{* * *} \mathrm{p} \leq 0.001$. In boxplots the median is marked with a horizontal line, mean with square, the box representing $25-75 \%$ percentiles and whiskers representing standard deviation.

\section{Results}

\subsection{Invading and dormant carcinoma cells feature distinct cell membrane structures}

HSC-3 cancer cell invasion into the uterus leiomyoma organotypic model was visualized using SEM (Fig. 1(A)) followed by immunohistochemistry with cytokeratin AE1/AE3-staining (Fig. 1(B)) and TEM (Fig. 1(C) and (D)). Carcinoma cells in the invasion front (dotted rectangle in 1B) featured invadopodia structures (Fig. 1(C), arrow), whereas in the upper part of the disc (solid rectangle in 1B), the non-invasive cells were mostly surrounded by basement 

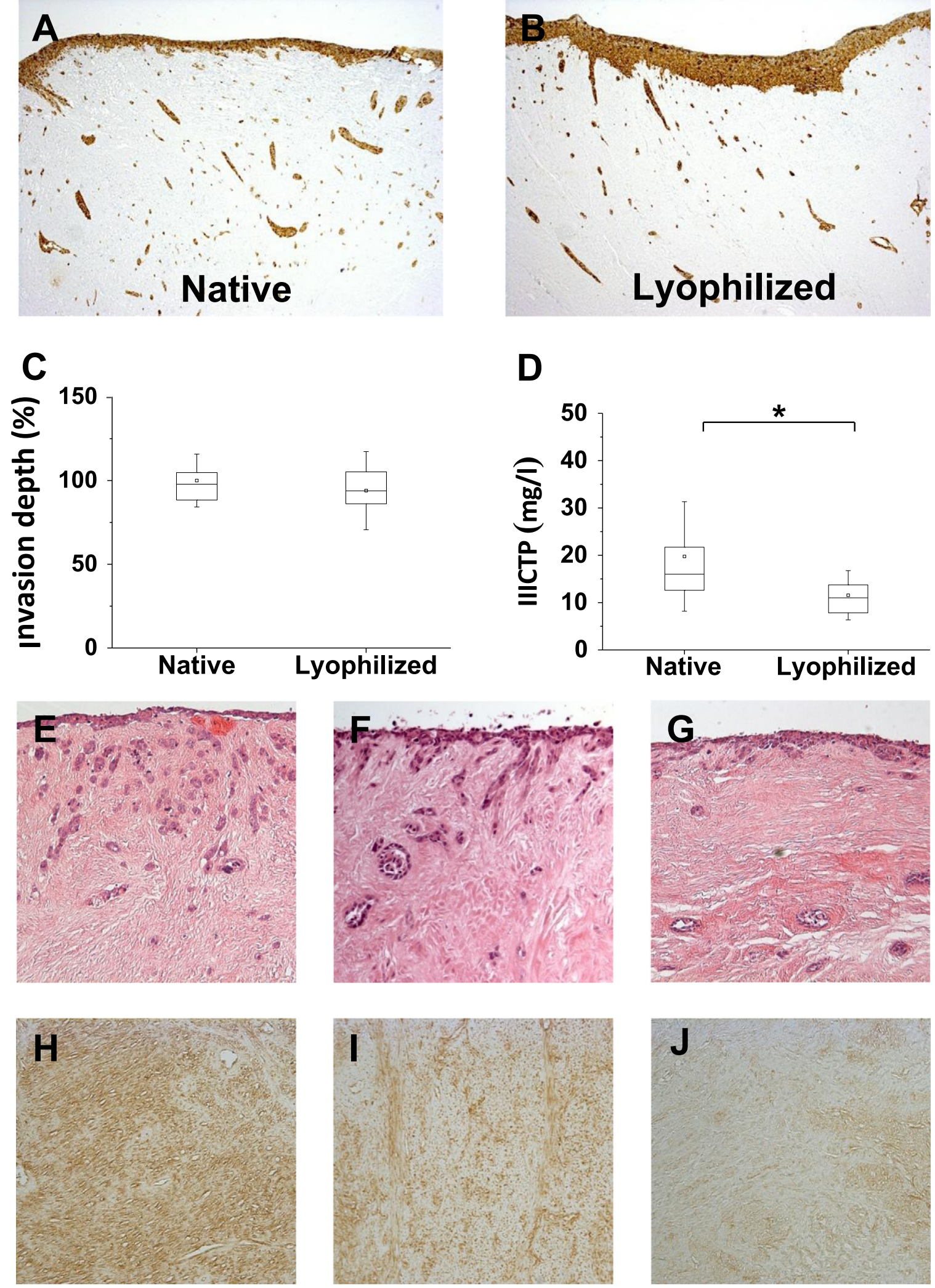

Fig. 3. HSC-3 cell invasion assay using native (A) and lyophilized (B) myoma discs. Invasion depths were analyzed from AE1/AE3 stained sections of native ( $\mathrm{n}=26)$ and lyophilized ( $n=19)$ myoma discs (C). Carboxy-terminal peptide of type III collagen (IIICTP) concentrations (which indicate type III collagen degradation) were analyzed using RIA from native $(n=9)$ and lyophilized $(n=12)$ myoma discs (D). HE staining of HSC-3 cells invading in various myoma discs from different patients (E - G) shows variation in invasion efficiencies between different types of patient samples. There is vast variation in the amount of tenascin-C in the matrix of different types of myomas from abundant (H) to scanty (J). * $\mathrm{p} \leq 0.05$. 
membrane structures (Fig. 1(D), arrow).

3.2. Lyophilization of the myoma model affects collagen degradation, but not the invasion pattern

We then tested if the HSC-3 invasion assay results from frozen native discs (Fig. 3(A)) could be recapitulated using lyophilized and rehydrated myoma discs (Fig. 3(B)). Based on the invasion depth analysis, no difference was found between the native or lyophilized discs (Fig. 3(C)). However, there was a statistically significant difference in IIICTP levels between lyophilized (11.6 mg/ 1) and native $(19.8 \mathrm{mg} / \mathrm{l})$ myoma assays, which indicates that the HSC-3 cells invading in lyophilized and rehydrated discs degraded less type III collagen than in native discs (Fig. 3(D)). However, it is important to note that although there were no differences in the pattern or depth of invasion between the native and lyophilized discs prepared from the same myoma samples, the mainly budding pattern of HSC-3 invasion (as well as SCC-15 and SCC-25, not shown) varied between discs from different patients (Fig. 3(E)-G). Therefore, different myomas should not be combined in one experimental set-up. Additionally, we recommend that every myoma for invasion assays should first be pretested - e.g. using "standard" HSC-3 carcinoma cells - to discard those myomas that have unusual invasion inductive properties. The variation of invasion efficiencies between myomas might partially be due to differences in invasion inductive matrix composition, such as the amount of TNC
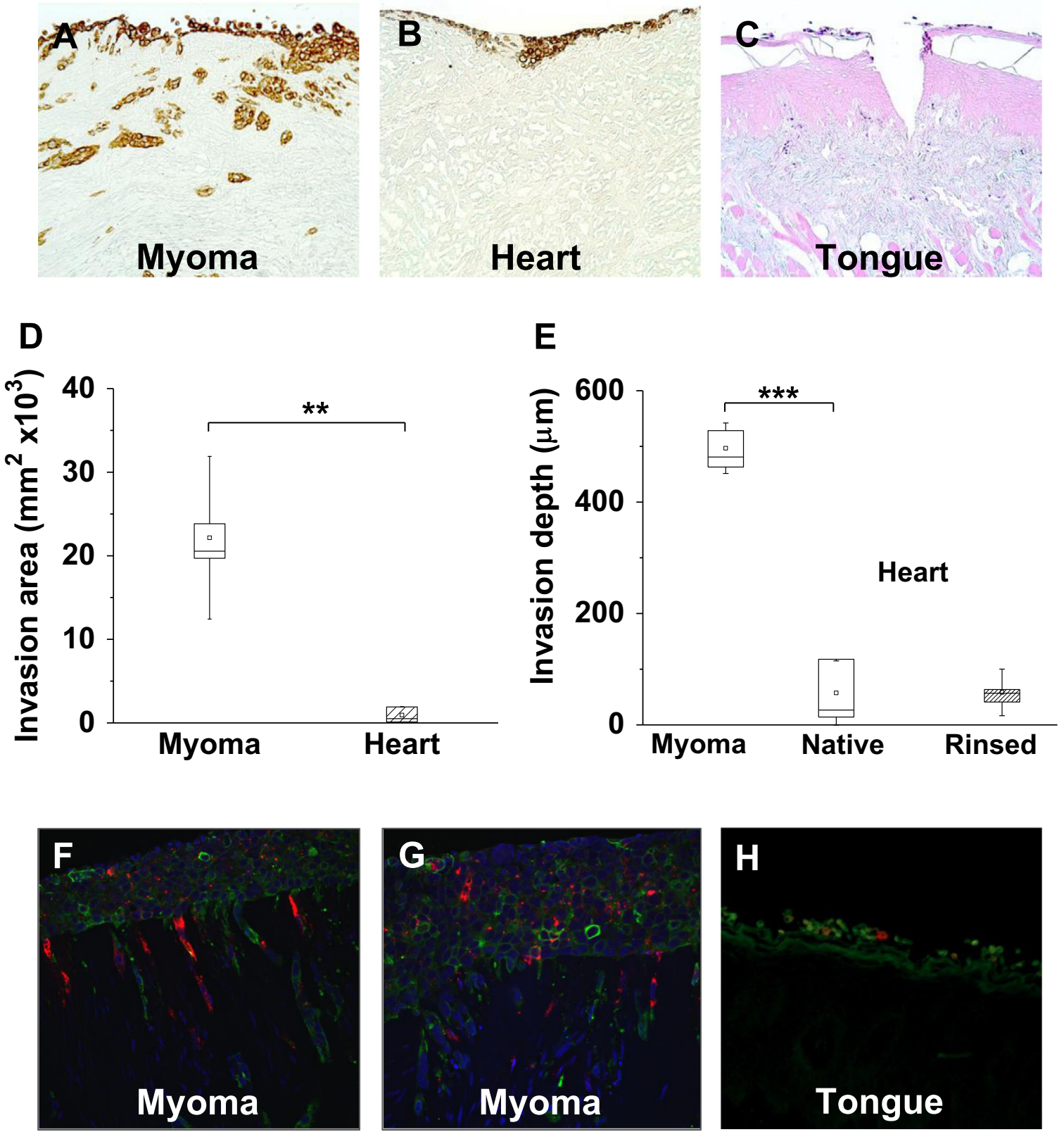

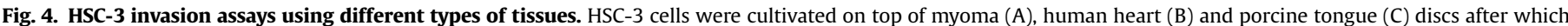

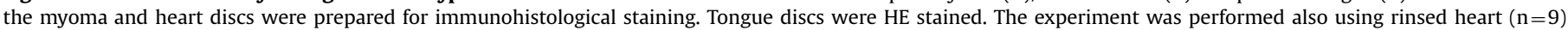

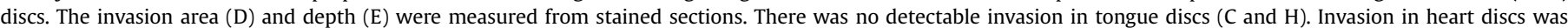

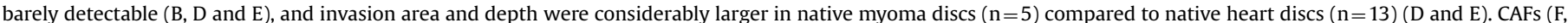

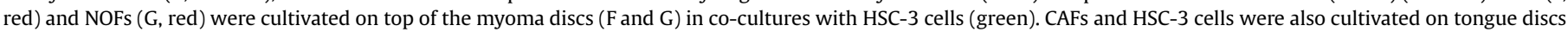

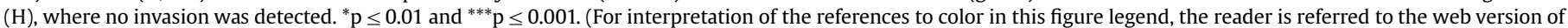
this article.) 
(Fig. 3(H)-J).

\subsection{Heart or tongue tissues do not attract HSC-3 invasion}

Using the highly invasive HSC-3 cell line we next tested if cancer cells are able to invade into healthy human heart tissue discs (Fig. 4(B)) as readily as they invade into myoma tissue (Fig. 4 (A)). Native myoma, and native and rinsed heart discs were used in this experiment. We found that there was only minimal invasion into the human heart matrix both in native and rinsed discs (Fig. 4
(B), D and E) and there was no invasion in mouse, rat or porcine heart tissue discs (not shown). Invasion depth and area in myoma were vastly larger compared to those in the heart (Fig. 4(D) and (E)). Since HSC-3 is an aggressive tongue carcinoma cell line, we also tested whether HSC-3 cells could invade into their "natural matrix", healthy tongue discs (Fig. 2). Although HSC-3 cells invaded into myoma, they showed hardly any penetration into the tongue discs (Fig. 4(C)), even after the surface was wounded as described before (Figs. 2 and $4(\mathrm{C})$ ). The tongue discs were not invaded (Fig. 4(H)) even after co-culturing HSC-3 cells (green) with
Myoma
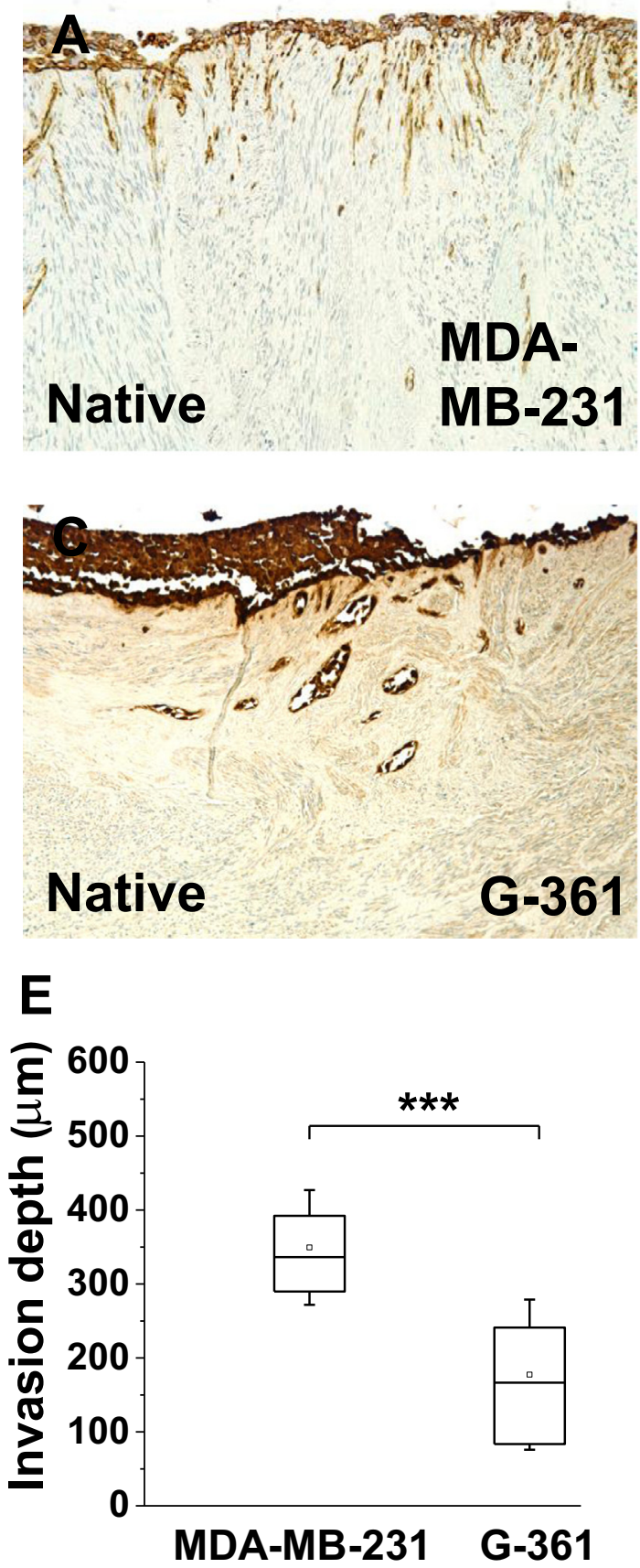

\section{Heart}
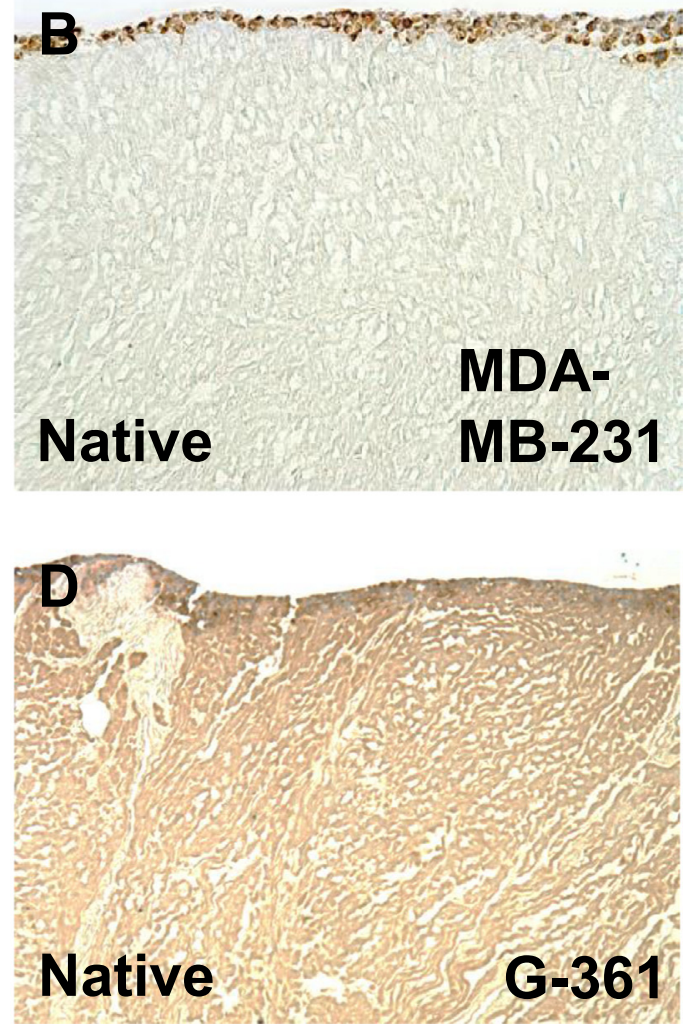

F

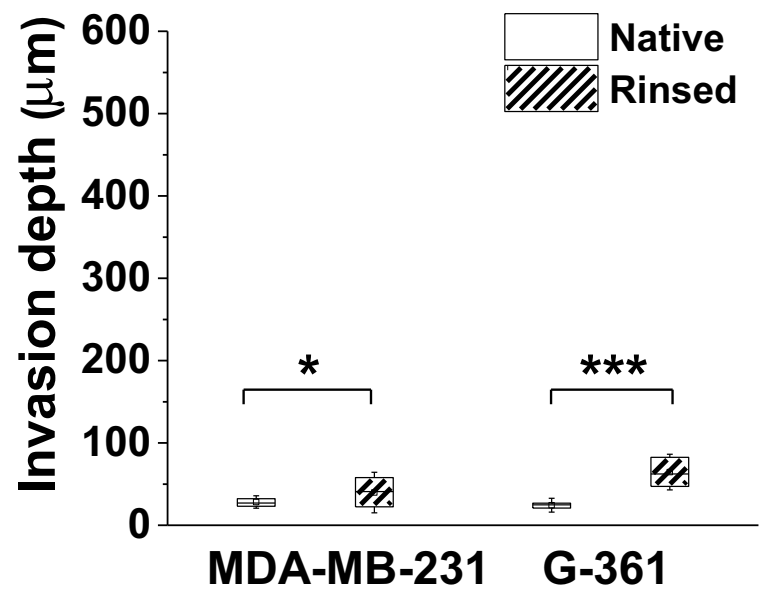

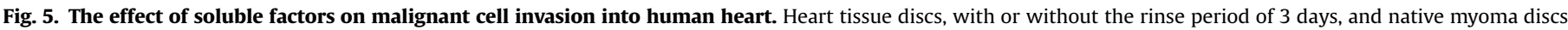

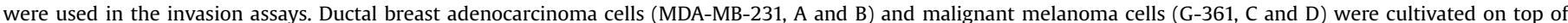

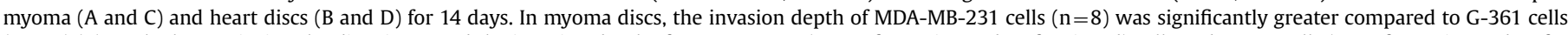

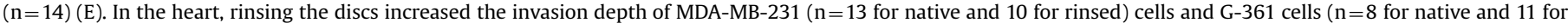
rinsed) cells (F). ${ }^{*} \mathrm{p} \leq 0.05$ and ${ }^{* * *} \mathrm{p} \leq 0.001$. 
CAFs or NOFs (red), unlike in myoma discs (Fig. 4(F) and (G)).

\subsection{Breast carcinoma and melanoma cells invade more in rinsed} heart matrix

Since the invasion efficiency of the HSC-3 cell line clearly differed between myoma and heart tissue discs, we tested other invasive cell lines in these matrices as well. The invasion of breast carcinoma MDA-MB-231 (Fig. 5(A) and (B)) and melanoma G-361 (Fig. 5(C) and (D)) cells in native myoma, and native and rinsed hearts was analyzed. In myoma, deeper invasion was detected using MDA-MB-231 cells in comparison to G-361 cells (Fig. 5(E)). Similar to HSC-3 cells, the breast carcinoma and melanoma cell lines showed poor invasion into the native solid matrix of the heart tissue (Fig. 4(D) and (E); Fig. 5(F)), but the invasion of all cell lines was slightly induced after rinsing off the soluble fraction of the heart matrix.

\subsection{Heart tissue contains migration inhibiting factors}

Next we analyzed the gel filtration fractions of human heart and myoma RM using wound healing scratch assays. We found that small molecular weight fractions from the heart rinsing media caused marked inhibition of HSC-3 migration compared to the similar size fractions from the myoma rinsing media (Fig. 6(A) and (B)). This suggests that the heart tissue contains soluble factors that are able to inhibit cancer cell migration, which most likely affects invasion as well.

3.6. Myoma tissue contains growth factors as well as their receptors and binding proteins

Since we have previously shown that rinsing myoma discs decreases invasion depth and increases type III collagen degradation [31], we wanted to elucidate the mechanisms of this effect and analyzed the protein content of the myoma rinse. In the myoma rinse we found a variety of growth factors as well as their receptors and binding proteins (Table 1 ), including various migration affecting growth factors, such as fibroblast growth factor 2 (FGF2), transforming growth factor beta (TGF- $\beta$ ) 1 and -2 and hepatocyte growth factor (HGF).

\section{Discussion}

Our group has developed a three-dimensional organotypic invasion assay based on human uterine leiomyoma tissue [23]. Here we found that the myoma discs also function in invasion assays after lyophilization and rehydration, which makes their utilization and shipment more straightforward. On the other hand, healthy human heart or porcine tongue discs did not induce invasion, and rinsing of the heart discs to remove soluble factors resulted in only a slight induction of invasion. Moreover, the small molecular weight molecules from human heart rinsing media inhibited cancer cell migration. These results demonstrate that non-neoplastic healthy tissue is less able to induce invasion, and furthermore that the migration inhibitory effects of heart tissue may partially be due to soluble factors released from the tissue.

The composition of TME in cancerous tissue, for example the presence of ECM molecules, cytokines and proteases, could include highly important predictors of cancer prognosis. ECM may limit cancer initiation at early stages, whereas after modification by cancer cells at later stages, it can drive tumor progression [26]. We have shown that depleting soluble factors by rinsing the myoma discs alters the invasion efficacy and pattern of aggressive oral cancer cells [31]. Here we demonstrated that, similar to rinsed
A

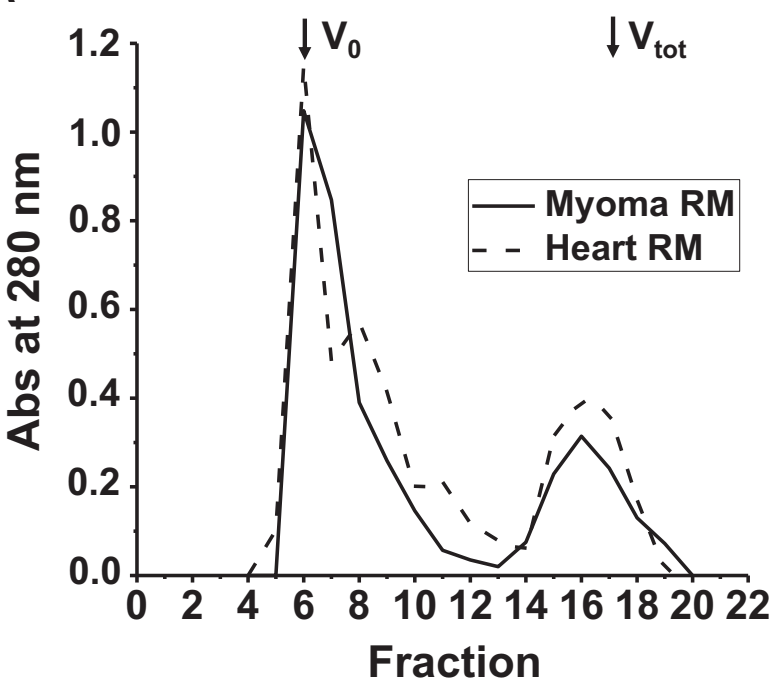

B

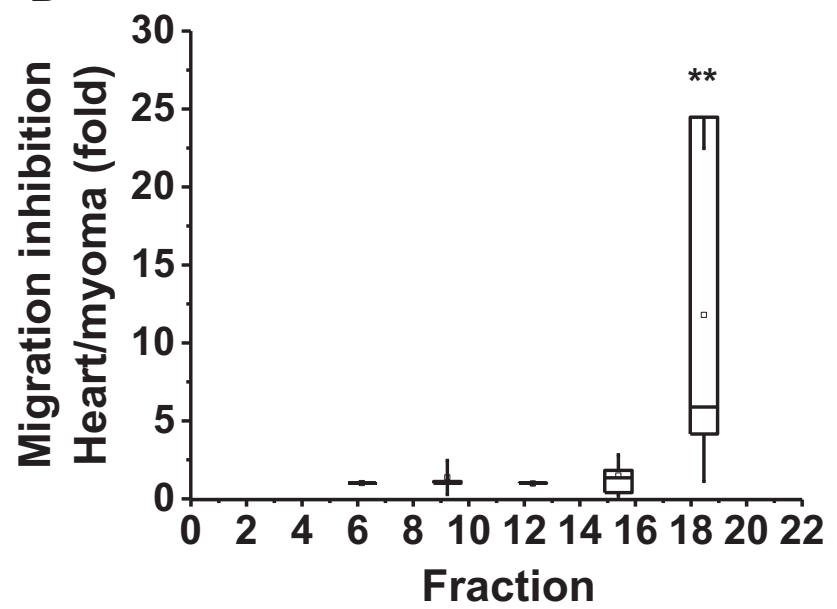

Fig. 6. Fractions of human heart and myoma rinsing media have distinct effects on HSC-3 cell migration. Two identical runs were performed. The small molecular weight fractions (Sephadex G-75 gel filtration fractions 17-19) (A) from the heart rinsing media (RM) caused a marked inhibition of the cell migration compared to the similar fractions from the myoma RM (B). The lines denote absorbance at $280 \mathrm{~nm}$ measured from the fractions (solid line, myoma RM; dashed line, heart RM) (A). The boxes ( $\mathrm{n}=6$ for each box) denote the ratio of migration inhibition of heart washings to that of the myoma washings (B). Identical pooled fractions (5-7, 8-10, 11-13, 14-16, and 17-19) from the two gel filtration runs were tested. The response to the pure cell culture medium was set to $1 . \mathrm{V}_{0}$, void volume; $\mathrm{V}_{\text {tot }}$, total volume of the column. ${ }^{* *} \mathrm{p} \leq 0.01$.

myomas [31], invading HSC-3 cells degraded type III collagen more efficiently in native than in lyophilized and rehydrated myoma discs. This indicates that lyophilization and rehydration alters the matrix structures and may allow cancer cells to invade the tissue with less need to degrade the collagen fibers. However, although the invasion mechanisms varied between native and lyophilized myoma matrix, there was no difference in invasion depth, which indicates that lyophilized myoma tissue could be utilized in invasion assays as well as native myoma.

Primary malignancies of the heart are extremely uncommon. Although primary cardiac tumors are rare, tumors that metastasize to the heart from other organs occur more commonly. These secondary tumors have an incidence of $1.23 \%$ in autopsy reports [16]. The most common tumors with cardiac metastatic potential are carcinomas of the lung, breast and esophagus, but also lymphoma, leukemia and melanoma cells have been found to metastasize to 
Table 1

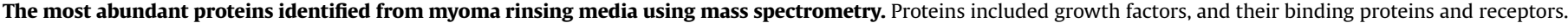
The gene coding the protein, name of the protein, top enriched biological process and cellular component are listed.

\begin{tabular}{|c|c|c|c|c|}
\hline & Gene & Protein & Top enriched BP & Cellular component \\
\hline \multicolumn{5}{|l|}{ Binding proteins } \\
\hline & IGFBP3 & Insulin-like growth factor-binding protein 3 & Apoptotic process & Extracellular \\
\hline & GRB2 & Growth factor receptor-bound protein 2 & Modulation by virus of host morphology or physiology & Plasma membrane \\
\hline & FGFBP1 & Fibroblast growth factor-binding protein 1 & Negative Regulation of cell proliferation & Extracellular \\
\hline & IGFBP7 & Insulin-like growth factor-binding protein 7 & Negative regulation of cell proliferation & Extracellular \\
\hline & IGFBP5 & Insulin-like growth factor-binding protein 5 & Signal transduction & Extracellular \\
\hline & HDGFRP2 & Hepatoma-derived growth factor-related protein 2 & Transcription, DNA-dependent & Nucleus \\
\hline & LTBP3 & $\begin{array}{l}\text { Latent-transforming growth factor beta-binding pro- } \\
\text { tein } 3\end{array}$ & $\begin{array}{l}\text { Transforming growth factor beta receptor signaling } \\
\text { pathway }\end{array}$ & Extracellular \\
\hline & LTBP4 & $\begin{array}{l}\text { Latent-transforming growth factor beta-binding pro- } \\
\text { tein } 4\end{array}$ & $\begin{array}{l}\text { Transforming growth factor beta receptor signaling } \\
\text { pathway }\end{array}$ & Extracellular \\
\hline \multicolumn{5}{|l|}{ Growth factors } \\
\hline & FGF2 & Fibroblast growth factor 2 & Apoptotic process & Extracellular \\
\hline & TGFB2 & Transforming growth factor beta- 2 & Axon guidance & Extracellular \\
\hline & HDGF & Hepatoma-derived growth factor & Cell proliferation & Extracellular \\
\hline & PDGFB & Platelet-derived growth factor subunit B & Negative regulation of transcription, DNA-dependent & Extracellular \\
\hline & PDGFA & Platelet-derived growth factor subunit A & Platelet activation & Extracellular \\
\hline & EGF & Pro-epidermal growth factor & Platelet activation & Extracellular \\
\hline & GDF9 & Growth/differentiation factor 9 & Positive regulation of cell proliferation & Extracellular \\
\hline & TGFB1 & Transforming growth factor beta- 1 & $\begin{array}{l}\text { Positive regulation of transcription from RNA polymerase } \\
\text { II promoter }\end{array}$ & Extracellular \\
\hline & VEGFA & Vascular endothelial growth factor A & $\begin{array}{l}\text { Positive regulation of transcription from RNA polymerase } \\
\text { II promoter }\end{array}$ & Extracellular \\
\hline & IGF1 & Insulin-like growth factor I & $\begin{array}{l}\text { Positive regulation of transcription from RNA polymerase } \\
\text { II promoter }\end{array}$ & Extracellular \\
\hline & HGF & Hepatocyte growth factor & $\begin{array}{l}\text { Positive regulation of transcription from RNA polymerase } \\
\text { II promoter }\end{array}$ & Extracellular \\
\hline & TGFB1I1 & $\begin{array}{l}\text { Transforming growth factor beta-1-induced transcript } \\
1 \text { protein }\end{array}$ & Positive regulation of transcription, DNA-dependent & Nucleus \\
\hline & IGF2 & Insulin-like growth factor II & Regulation of transcription, DNA-dependent & Extracellular \\
\hline & CTGF & Connective tissue growth factor & Small molecule metabolic process & Extracellular \\
\hline \multicolumn{5}{|l|}{ Receptors } \\
\hline & TGFBR2 & TGF-beta receptor type-2 & Apoptotic process & Plasma membrane \\
\hline & FGFR3 & Fibroblast growth factor receptor 3 & Apoptotic process & Plasma membrane \\
\hline & FGFR2 & Fibroblast growth factor receptor 2 & Apoptotic process & Extracellular \\
\hline & NTRK1 & High affinity nerve growth factor receptor & Axon guidance & Plasma membrane \\
\hline & EPS15 & Epidermal growth factor receptor substrate 15 & Cell proliferation & Plasma membrane \\
\hline & IGF1R & Insulin-like growth factor 1 receptor & Immune response & Plasma membrane \\
\hline & PDGFRA & Platelet-derived growth factor receptor alpha & Modulation by virus of host morphology or physiology & Plasma membrane \\
\hline & KDR & Vascular endothelial growth factor receptor 2 & Modulation by virus of host morphology or physiology & Extracellular \\
\hline & EGFR & Epidermal growth factor receptor & Negative regulation of apoptotic process & Extracellular \\
\hline & FRS2 & Fibroblast growth factor receptor substrate 2 & Neurotrophin TRK receptor signaling pathway & Plasma membrane \\
\hline & MET & Hepatocyte growth factor receptor & $\begin{array}{l}\text { Positive regulation of transcription from RNA polymerase } \\
\text { II promoter }\end{array}$ & Extracellular \\
\hline & FGFR1 & Fibroblast growth factor receptor 1 & Transcription, DNA-dependent & Extracellular \\
\hline
\end{tabular}

the heart $[9,28]$. Carcinoma cells metastasize into the epicardium preferably via a lymphatic route while many tumors, especially lymphoma and melanoma, can invade into the myocardium via a hematogenous route $[17,28]$. It is speculated that intracavitary pressure, high blood flow and contractile strength may protect the heart from metastatic invasion [9]. Obviously, the heart ECM around the striated muscle myocytes also differs from most other tissue matrices, and may explain why cancer cells do not invade into it.

We showed that in addition to the HSC-3 cells, also the metastatic breast cancer or malignant melanoma cell lines did not invade into the heart tissue discs. Invasion of cancer cell lines through myoma tissue can be seen via existing vessels within the myoma matrix. However, the vessels of human heart discs were not utilized for invasion. We demonstrated that one explanation for this anti-invasive effect could be the presence of soluble inhibitory factors within the heart tissue. Especially in the case of malignant melanoma cells, rinsing off the soluble compounds enhanced the cell invasion. However, even then the depth of invasion of melanoma cells was not at the same level as in myoma discs. In the case of breast and tongue cancer the invasion was also increased in rinsed discs, but the differences were less obvious. This indicates that heart tissue has inhibitory fractions that affect cell invasion. In fact, in a migration assay, small molecular weight fractions from heart rinsing media significantly inhibited the migration of the HSC-3 cell line. The identification of these soluble inhibitory factors and their effects on various cancer cell lines are exciting topics for further studies.

In the invasion assays, the most "natural TME" for HSC-3 cells, the porcine tongue tissue, was unable to induce their invasion. Even after adding myoma disc rinsing media as chemoattractant, invasion into the tongue was not induced. We then tested whether CAFs could enhance invasion induction into tongue discs. CAFs are known to have a role in carcinoma invasion in vivo by causing so called "fibroblast-led collective invasion" [12]. CAFs form the leading edge of invading cells (Fig. $4(\mathrm{~F})$ ) and make a path for carcinoma cells to follow, as well as serve as a prognostic indicator in oral squamous cell carcinoma (OSCC) [7]. We added CAFs together with HSC-3 cells on top of myoma and tongue discs. Although HSC-3 cells invaded myoma as expected, the addition of 
CAFs did not induce invasion of tongue discs. In addition, bone marrow mesenchymal stem cells that we have shown to be able to induce HSC-3 invasion in myoma [30] were not able to induce HSC-3 invasion into the tongue tissue discs. This may be due to species differences (human myoma versus porcine tongue). Most likely, however, it is because myoma, unlike healthy tongue, presents an ECM that mimics the tumor microenvironment phenotype. This tumor ECM differs from that of healthy tissue in that it contains e.g. more laminins, type IV collagen, lysyl-oxidase-1 (LOX1) $[23,31]$ and tenascin- $C$, as shown here in the myoma matrix (Fig. 3(H)-J).

Finally, in order to elucidate the previously detected decrease in invasion depth and increase in collagen degradation in rinsed myoma matrix [31], we deprived myoma tissue of its soluble factors by rinsing and analyzed the rinsing media utilizing mass spectrometry. This revealed a variety of growth factors as well as their binding proteins and receptors (Table 1). Some of these growth factors are known for their migration enhancing nature, including FGF2, TGF- $\beta 1$ and -2 and HGF. Of these growth factors, TGF- $\beta 1$ and HGF are of special interest, since TGF- $\beta 1$ induced myofibroblasts are shown to secrete HGF that increases invasion of OSCC cells in vitro $[6,18]$. Additionally, TGF- $\beta 1$ induces an epithelial-mesenchymal transition (EMT) in OSCC cells, a process in which cells of epithelial origin gain properties of mesenchymal cells, including loss of adhesion and increased migratory capabilities [25]. Some of the changes between invasion in native and rinsed myomas detected previously [31] could be attributed to these migration and invasion increasing growth factors in myoma rinsing media. However, as we have established, individual myomas vary in terms of composition and invasion aiding capabilities. Hence it cannot be deduced that all myomas contain these same growth factors in similar proportions. This variation in proportions of growth factors could lead to different responses in cells invading into the myoma, a complexity known also from different types of cancers. An excellent example of this complexity is TGF- $\beta$, which was prominent in myoma rinsing media; it possesses both pro- and anti-tumorigenic features depending on the state of both the microenvironment and the cancer cells [20]. The varying interactions of cancer cells with soluble and insoluble factors of TME remain a topic for further studies. What are the cumulative interactions leading to enhancement or inhibition of invasion, and could new treatments be generated to modulate these interactions?

In conclusion, the importance of TME in carcinogenesis is well recognized. This provides the rationale behind the use of human tumor-derived matrix for cancer invasion studies rather than rodent or synthetic tumor matrices. Myoma is therefore an ideal tool to obtain answers of the co-operative behavior of the cells in the complex TME mimicking tumor matrix. However, myomas of single origin should be used in each experimental set-up. As demonstrated here, neither the healthy human tissue discs nor healthy porcine, mouse or rat tissue, either tongue or heart, supported invasive cancer growth. Furthermore, we demonstrated that soluble factors from human heart inhibited cancer migration and invasion in vitro. These so far uncharacterized factors may also partially explain why primary tumors or metastases rarely invade into the human heart.

\section{Acknowledgments}

We thank Mrs. Maija-Leena Lehtonen for her guidance and excellent technical help in cell culture and experiments, Mrs. Tanja Kuusisto for performing immunohistochemical stainings and Biocenter EM core technicians for preparing EM samples. Doctors
Tuomas Mäkelä and Fredrik Yannopoulos are acknowledged for their guidance and co-operation in harvesting porcine tongues and Professor Petri Lehenkari for providing the porcine tongues. The authors thank Professor Miklós Tóth for kindly providing us with the human heart sample. Mrs. Katja Koukkula is acknowledged for her work on RIA. We thank Doctor Ahmed Al-Samadi for reviewing this article and providing excellent feedback. This work was supported by the Academy of Finland, Sigrid Juselius Foundation, Finnish Cancer Foundation, Finnish Foundation for Cardiovascular Research, Medical Research Center Oulu, Finnish Dental Society Apollonia and research funds from the Medical Faculty of the University of Oulu and Oulu University Hospital special state support for research.

\section{References}

[1] M. Agostini, L.Y. Almeida, D.C. Bastos, R.M. Ortega, F.S. Moreira, F. Seguin, K. G. Zecchin, H.F. Raposo, H.C.F. Oliveira, N.D. Amoêdo, T. Salo, R.D. Coletta, E. Graner, The fatty acid synthase inhibitor orlistat reduces the growth and metastasis of orthotopic tongue oral squamous cell carcinomas, Mol. Cancer Ther. 13 (3) (2014) 585-595, http://dx.doi.org/10.1158/1535-7163.MCT-121136.

[2] I. Alahuhta, M. Aikio, O. Väyrynen, S. Nurmenniemi, J. Suojanen, S. Teppo, T. Pihlajaniemi, R. Heljasvaara, T. Salo, P. Nyberg, Endostatin induces proliferation of oral carcinoma cells but its effect on invasion is modified by the tumor microenvironment, Exp. Cell Res. 336 (1) (2015) 130-140, http://dx.doi. org/10.1016/j.yexcr.2015.06.012.

[3] M. Allen, J. Louise Jones, Jekyll and Hyde: the role of the microenvironment on the progression of cancer, J. Pathol. 223 (2) (2011) 162-176, http://dx.doi.org/ 10.1002/path.2803.

[4] A. Almangush, I.O. Bello, H. Keski-Säntti, L.K. Mäkinen, J.H. Kauppila, M. Pukkila, J. Hagström, J. Laranne, S. Tommola, O. Nieminen, Y. Soini, V.M. Kosma, P. Koivunen, R. Grénman, I. Leivo, T. Salo, Depth of invasion, tumor budding, and worst pattern of invasion: prognostic indicators in early-stage oral tongue cancer, Head Neck 36 (6) (2014) 811-818, http://dx.doi.org/ $10.1002 /$ hed.23380.

[5] P. Åström, E. Pirilä, R. Lithovius, H. Heikkola, J.T. Korpi, M. Hernández, T. Sorsa, T. Salo, Matrix metalloproteinase-8 regulates transforming growth factor-ß1 levels in mouse tongue wounds and fibroblasts in vitro, Exp. Cell Res. 328 (1) (2014) 217-227, http://dx.doi.org/10.1016/j.yexcr.2014.07.010.

[6] P.J. Barth, T.S. Zu Schweinsberg, A. Ramaswamy, R. Moll, CD34+fibrocytes, a-smooth muscle antigen-positive myofibroblasts, and CD117 expression in the stroma of invasive squamous cell carcinomas of the oral cavity, pharynx, and larynx, Virchows Arch. 444 (3) (2004) 231-234, http://dx.doi.org/10.1007/ s00428-003-0965-1.

[7] I.O. Bello, M. Vered, D. Dayan, A. Dobriyan, R. Yahalom, K. Alanen, P. Nieminen, S. Kantola, E. Läärä, T. Salo, Cancer-associated fibroblasts, a parameter of the tumor microenvironment, overcomes carcinoma-associated parameters in the prognosis of patients with mobile tongue cancer, Oral. Oncol. 47 (1) (2011) 33-38, http://dx.doi.org/10.1016/j.oraloncology.2010.10.013.

[8] C.C. Bitu, J.H. Kauppila, A. Bufalino, S. Nurmenniemi, S. Teppo, M. Keinänen, S.T. Vilen, P. Lehenkari, P. Nyberg, R.D. Coletta, T. Salo, Cathepsin K is present in invasive oral tongue squamous cell carcinoma in vivo and in vitro, PLoS One 8 (8) (2013) e70925, http://dx.doi.org/10.1371/journal.pone.0070925.

[9] R. Bussani, F. De-Giorgio, A. Abbate, F. Silvestri, Cardiac metastases, J. Clin. Pathol. 60 (1) (2007) 27-34, http://dx.doi.org/10.1136/jcp.2005.035105.

[10] D.E. Costea, A.O.E. Dimba, L.L. Loro, O.K. Vintermyr, A.C. Johannessen, The phenotype of in vitro reconstituted normal human oral epithelium is essentially determined by culture medium, J. Oral. Pathol. Med. 34 (4) (2005) 247-252, http://dx.doi.org/10.1111/j.1600-0714.2005.00308.x.

[11] D. Dayan, T. Salo, S. Salo, P. Nyberg, S. Nurmenniemi, D.E. Costea, M. Vered, Molecular crosstalk between cancer cells and tumor microenvironment components suggests potential targets for new therapeutic approaches in mobile tongue cancer Cancer, Cancer Med. 1 (2) (2012) 128-140, http://dx.doi. org/10.1002/cam4.24

[12] C. Gaggioli, S. Hooper, C. Hidalgo-Carcedo, R. Grosse, J.F. Marshall, K. Harrington, E. Sahai, Fibroblast-led collective invasion of carcinoma cells with differing roles for RhoGTPases in leading and following cells, Nat. Cell Biol. 9 (12) (2007) 1392-1400, http://dx.doi.org/10.1038/ncb1658.

[13] D. Hanahan, R.A. Weinberg, The hallmarks of cancer, Cell 100 (1) (2000) 57-70, http://dx.doi.org/10.1016/S0092-8674(00)81683-9.

[14] D. Hanahan, R.A. Weinberg, Hallmarks of cancer: the next generation, Cell 144 (5) (2011) 646-674, http://dx.doi.org/10.1016/j.cell.2011.02.013.

[15] M. Heinonen, A. Hemmes, K. Salmenkivi, K. Abdelmohsen, S.-T. Vilén, M. Laakso, M. Leidenius, T. Salo, S. Hautaniemi, M. Gorospe, P. Heikkilä, C. Haglund, A. Ristimäki, Role of RNA binding protein HuR in ductal carcinoma in situ of the breast, J. Pathol. 224 (4) (2011) 529-539, http://dx.doi.org/ 10.1002 /path.2889.

[16] Yin Lam King, P. Dickens, A.C.L. Chan, Tumors of the heart: a 20-year 
experience with a review of 12485 consecutive autopsies, Arch. Pathol. Lab. MEd. 117 (10) (1993) 1027-1031.

[17] E.C. Klatt, D.R. Heitz, Cardiac metastases, Cancer 65 (6) (1990) 1456-1459, http://dx.doi.org/10.1002/1097-0142(19900315)65:6<1456:: AID-CNCR2820650634 > 3.0.CO;2-5.

[18] M.P. Lewis, K.A. Lygoe, M.L. Nyström, W.P. Anderson, P.M. Speight, J.F. Marshall, G.J. Thomas, Tumour-derived TGF- $\beta 1$ modulates myofibroblast differentiation and promotes HGF/SF-dependent invasion of squamous carcinoma cells, Br. J. Cancer 90 (4) (2004) 822-832, http://dx.doi.org/10.1038/sj.bjc.6601611.

[19] T. Mäkelä, F. Yannopoulos, K. Alestalo, J. Mäkelä, P. Lepola, V. Anttila, S. Lehtonen, K. Kiviluoma, R. Takalo, T. Juvonen, P. Lehenkari, Intra-arterial bone marrow mononuclear cell distribution in experimental global brain ischaemia, Scand. Cardiovasc J. 47 (2) (2013) 114-120, http://dx.doi.org/ 10.3109/14017431.2012.750377.

[20] J. Massagué, TGF $\beta$ in Cancer, Cell 134 (2) (2008) 215-230, http://dx.doi.org/ 10.1016/j.cell.2008.07.001.

[21] K.A. Moutasim, M.L. Nyström, G.J. Thomas, Cell migration and invasion assays, Methods Mol. Biol. 731 (2011) 333-343, http://dx.doi.org/10.1007/9781-61779-080-5_27.

[22] S. Nurmenniemi, M.-K. Koivula, P. Nyberg, T. Tervahartiala, T. Sorsa, P. S. Mattila, T. Salo, J. Risteli, Type I and III collagen degradation products in serum predict patient survival in head and neck squamous cell carcinoma, Oral. Oncol. 48 (2) (2012) 136-140, http://dx.doi.org/10.1016/j. oraloncology.2011.09.002.

[23] S. Nurmenniemi, T. Sinikumpu, I. Alahuhta, S. Salo, M. Sutinen, M. Santala, J. Risteli, P. Nyberg, T. Salo, A novel organotypic model mimics the tumor microenvironment, Am. J. Pathol. 175 (3) (2009) 1281-1291, http://dx.doi.org/ 10.2353/ajpath.2009.081110.

[24] E. Pirilä, O. Väyrynen, E. Sundquist, K. Päkkilä, P. Nyberg, S. Nurmenniemi, V. Pääkkönen, P. Pesonen, D. Dayan, M. Vered, L. Uhlin-Hansen, T. Salo, Macrophages modulate migration and invasion of human tongue squamous cell carcinoma, PLoS One 10 (3) (2015) e0120895, http://dx.doi.org/10.1371/journal.pone.0120895.
[25] B. Qiao, N.W. Johnson, J. Gao, Epithelial-mesenchymal transition in oral squamous cell carcinoma triggered by transforming growth factor- $\beta 1$ is Snail family-dependent and correlates with matrix metalloproteinase-2 and -9 expressions, Int. J. Oncol. 37 (3) (2010) 663-668, http://dx.doi.org/10.3892/ ijo_00000715.

[26] D.F. Quail, J.A. Joyce, Microenvironmental regulation of tumor progression and metastasis, Nat. Med. 19 (11) (2013) 1423-1437, http://dx.doi.org/10.1038/ nm.3394.

[27] N. Rath, M.F. Olson, Rho-associated kinases in tumorigenesis: re-considering ROCK inhibition for cancer therapy, EMBO Rep. 13 (10) (2012) 900-908, http: //dx.doi.org/10.1038/embor.2012.127.

[28] K. Reynen, U. Köckeritz, R.H. Strasser, Metastases to the heart, Ann. Oncol. 15 (3) (2004) 375-381, http://dx.doi.org/10.1093/annonc/mdh086.

[29] L. Risteli, J. Risteli, Analysis of extracellular matrix proteins in biological fluids Methods Enzymol. 145 (1987) 391-411.

[30] S. Salo, C. Bitu, K. Merkku, P. Nyberg, I.O. Bello, J. Vuoristo, M. Sutinen, H. Vähänikkilä, D.E. Costea, J. Kauppila, P. Lehenkari, D. Dayan, M. Vered, J. Risteli, T. Salo, Human bone marrow mesenchymal stem cells induce collagen production and tongue, Cancer Invasion PLoS One 8 (10) (2013) e77692, http://dx.doi.org/10.1371/journal.pone.0077692.

[31] S. Teppo, E. Sundquist, M. Vered, H. Holappa, J. Parkkisenniemi, T. Rinaldi, P. Lehenkari, R. Grenman, D. Dayan, J. Risteli, T. Salo, P. Nyberg, The hypoxic tumor microenvironment regulates invasion of aggressive oral carcinoma cells, Exp. Cell Res. 319 (4) (2013) 376-389, http://dx.doi.org/10.1016/j. yexcr.2012.12.010.

[32] P.A. Torzilli, J.W. Bourne, T. Cigler, C.T. Vincent, A new paradigm for mechanobiological mechanisms in tumor metastasis, Semin Cancer Biol. 22 (5-6) (2012) 385-395, http://dx.doi.org/10.1016/j.semcancer.2012.05.002.

[33] M. Vered, M. Lehtonen, L. Hotakainen, E. Pirilä, S. Teppo, P. Nyberg, R. Sormunen, A. Zlotogorski-Hurvitz, T. Salo, D. Dayan, Caveolin-1 accumulation in the tongue cancer tumor microenvironment is significantly associated with poor prognosis: an in-vivo and in-vitro study, BMC Cancer 15 (1) (2015) 25, http://dx.doi.org/10.1186/s12885-015-1030-6. 